\title{
Effect of Soil Fertility Constraints based Nutrient Management on Growth, Yield and Quality Parameters of Groundnut (Arachis hypogaea L.) at Kurthkoti-2 Micro-watershed, Gadag
}

\author{
Malatesh Kambali* and S. S. Gundlur \\ Department of Soil Science and Agricultural Chemistry, University of Agricultural Sciences, \\ Dharwad-580 005, Karnataka, India \\ *Corresponding author
}

A B S T R A C T

Keywords

Groundnut,

Fertility constraints, Kharif, Microwatershed

Article Info

Accepted:

30 May 2020

Available Online:

10 June 2020
A field experiment was conducted to study the effect of soil fertility constraints based nutrient management on groundnut (Arachis hypogaea L.) at Kurthkoti-2 micro-watershed, Gadag. The RCBD was imposed with ten treatments replicated thrice. The non-gravelly, clay textured black soils belong to Typic Chromustert with moderately alkaline $\mathrm{pH}$ having low to medium fertility status $\left(\mathrm{N}, \mathrm{P}_{2} \mathrm{O}_{5}, \mathrm{~K}_{2} \mathrm{O}\right.$ and $\mathrm{S}: 180,20.5,351$ and $\left.17.5 \mathrm{~kg} \mathrm{ha}^{-1}\right)$ significantly responded in terms of groundnut growth and yield during kharif 2018. Soil application of $175 \% \mathrm{RD} \mathrm{N}, \mathrm{P}_{2} \mathrm{O}+75 \% \mathrm{~K}_{2} \mathrm{O}$ nutrients recorded the significantly higher growth parameters i.e. plant height $(19.86,35.00$ and $45.80 \mathrm{~cm})$, number of branches plant ${ }^{-1}(5.74,6.60$ and 6.74$)$ and dry matter per plant $(6.78,17.43$ and $26.85 \mathrm{~g})$ at different stages (30, 60 DAS and at harvest respectively) along with significant higher yield attributes i.e. number of pods plant $^{-1}(22.46)$, pod weight plant $^{-1}(11.62 \mathrm{~g})$, shelling per cent $(85.34 \%)$ and test weight $(41.66 \mathrm{~g})$. Further the same treatment recorded significantly higher pod $\left(2898 \mathrm{~kg} \mathrm{ha}^{-1}\right)$ and haulm $\left(3848 \mathrm{~kg} \mathrm{ha}^{-1}\right)$ yield with an increase in the oil $(44.67 \%)$ and protein $(22.20 \%)$ contents in kernel.

\section{Introduction}

In rainfed locales of India, dilapidated soil fertility and nutrient imbalances are major issues influencing agricultural productivity. Organic matter levels have declined sharply in intensively cropped regions, prompting stale yields of real sustenance of major food crops. Notwithstanding a widespread insufficiency of nitrogen $(\mathrm{N})$, inadequacies of phosphorus $(\mathrm{P})$, sulfur $(\mathrm{S})$ and micronutrients are developing as imperatives for sustaining and additionally upgrading profitability under intensive crop production systems. It is evaluated that $29.4 \mathrm{~m}$ 
ha of soils in India are encountering a decline in fertility with a net negative parity of 8 to 10 Mt of nutrients per year (Srinivasarao, 2011). Poor nutrient use efficiency is another reason for concern. So far, soil fertility issues have been addressed predominantly in irrigated agriculture, yet late examinations have shown that drylands are parched as well as ravenous.

In the ongoing past, the concept of watershed based functional relation between parts and the whole development has emerged as one of the potential holistic approaches in rainfed areas, prompting to higher productivity and sustainability in agriculture. Assessment of fertility status and nutrient mapping of soils are an integral part of the watershed, which is needed to identify the extent of soils deficient in nutrients for site-specific recommendations. Soil fertility maps generated by UAS Dharwad under the Sujala-III watershed project of Karnataka during 2017-18 are taken as base maps to locate fertility constraints. Equally essential is the redefinition of soil fert ility assessment criteria in the light of altering c

rop production scenarios where financial yield response due to nutrient input are usually rep orted on soils categorized as ' medium ' or ' ele vated ' fertility soils (Das et al., 2015). Unless fertilizer application connotes soil-test based nutrient management, it is no longer 'balanced'. Unfortunately, actual field-based information on soil-test based nutrient management are scarce. The soil-test based nutrient management involving all deficient nutrients have been seldom attempted on cultivator's fields. So, there is, a pressing need to generate recommendations to gain sustained higher productivity and farm profit in the adverse climate. With this backdrop, a scientific look was initiated on an evaluation of multi-nutrient deficiencies in specific site and their redressal via graded levels of fertilizers on groundnut- the major crop of Northern dry zone-3 of Karnataka.

\section{Materials and Methods}

As a part of the present investigation, the test crop groundnut (GPBD- 4) was grown during Kharif 2018 in the farm fields of KVK Hulkoti. The experimental site is situated near Kurthkoti village (Survey no. 321) belong to Gadag district of Karnataka with a latitude of $15^{\circ} 22^{\prime} 36^{\prime \prime} \mathrm{N}$ and a longitude of $75^{\circ} 31^{\prime} 43^{\prime \prime} \mathrm{E}$ which comes under Northern dry zone of Karnataka state (Fig. 1). The rainfall received in all the months during the crop growth period ranged from $34.39 \mathrm{~mm}$ (October) to 130.07 (June) $\mathrm{mm}$. The experimental site is good cultivable land with runoff limitation due to drainage. It suits moderately (S2) for groundnut cultivation. Non-gravelly, very deep $(>150 \mathrm{~cm})$ clay textured black soils belong to Typic Chromustert (Fig. 2). A composite soil sample from $0-20 \mathrm{~cm}$ depth was collected from the experimental site before initiating the experiment and analyzed for chemical properties and fertility status. The results are presented in Table 1.

The soil fertility maps generated under SUJALA-III watershed project, UAS, Dharwad were taken as base maps to locate the soil fertility constraint for groundnut production. The maps implies that available nitrogen, phosphorus, boron and zinc were found deficient whereas sulphur and organic carbon were medium in range and potassium and iron were high in available status at the selected site (Survey no. 321) for the field experiment. Based on these facts the following modification in $\mathrm{RDF}$ was made. i.e. $\mathrm{T}_{1}$ : Control (RPP), $\mathrm{T}_{2}: 125 \% \mathrm{RD} \mathrm{N}$ and $\mathrm{P}_{2} \mathrm{O}_{5}+$ $25 \% \mathrm{~K}_{2} \mathrm{O}, \mathrm{T}_{3}: 125 \% \mathrm{RD} \mathrm{N}$ and $\mathrm{P}_{2} \mathrm{O}_{5}+50 \%$ $\mathrm{K}_{2} \mathrm{O}, \mathrm{T}_{4}: 125 \% \mathrm{RD} \mathrm{N}$ and $\mathrm{P}_{2} \mathrm{O}_{5}+75 \% \mathrm{~K}_{2} \mathrm{O}$, $\mathrm{T}_{5}: 150 \% \mathrm{RD} \mathrm{N}$ and $\mathrm{P}_{2} \mathrm{O}_{5}+25 \% \mathrm{~K}_{2} \mathrm{O}, \mathrm{T}_{6}$ : $150 \% \mathrm{RD} \mathrm{N}$ and $\mathrm{P}_{2} \mathrm{O}_{5}+50 \% \mathrm{~K}_{2} \mathrm{O}, \mathrm{T}_{7}: 150$ $\% \mathrm{RD} \mathrm{N}$ and $\mathrm{P}_{2} \mathrm{O}_{5}+75 \% \mathrm{~K}_{2} \mathrm{O}, \mathrm{T}_{8}: 175 \% \mathrm{RD}$ $\mathrm{N}$ and $\mathrm{P}_{2} \mathrm{O}_{5}+25 \% \mathrm{~K}_{2} \mathrm{O}, \mathrm{T}_{9}: 175 \% \mathrm{RD} \mathrm{N}$ and $\mathrm{P}_{2} \mathrm{O}_{5}+50 \% \mathrm{~K}_{2} \mathrm{O}$ and $\mathrm{T}_{10}: 175 \% \mathrm{RD} \mathrm{N}$ and $\mathrm{P}_{2} \mathrm{O}_{5}+75 \% \quad \mathrm{~K}_{2} \mathrm{O}$. RPP is $(25: 50: 25$ 
$\mathrm{N}: \mathrm{P}_{2} \mathrm{O}_{5}: \mathrm{K}_{2} \mathrm{O} \mathrm{kg} \mathrm{ha}^{-1} \mathrm{FYM} @ 5 \mathrm{t} \mathrm{ha}^{-1}+$ Gypsum $500 \mathrm{~kg} \mathrm{ha}^{-1}+10 \mathrm{~kg} \mathrm{ha}^{-1} \mathrm{ZnSO}_{4}+10$ $\mathrm{kg} \mathrm{ha}^{-1} \mathrm{FeSO}_{4}+$ Rhizobium @ $1000 \mathrm{~g} \mathrm{ha}^{-1}+$ PSB @ $1000 \mathrm{~g} \mathrm{ha}^{-1}$ ) was common for all the treatments. The treatments were replicated thrice in Randomized Complete Block Design with plot dimensions $4.2 \mathrm{~m} \times 4.4 \mathrm{~m}$. The biometric observations were recorded at 30 , 60 DAS and at maturity.

Shelling per cent was computed by (kernel weight/ pod weight $) \times 100$. Oil content was estimated by Nuclear Magnetic Resonance (NMR, Oxford 4000). The oil yield per hectare was worked out by the formula (Oil content $\times$ Shelling per cent $\times$ Pod yield $) / 10^{4}$ and expressed in $\mathrm{kg} \mathrm{ha}^{-1}$.

The soil samples were processed and analyzed for $\mathrm{pH}(1: 2.5)$, EC (1:2.5), OC by Walkley and Black's wet oxidation method (Sparks, 1996). Free $\mathrm{CaCO}_{3}$, particle density and particle size distribution (Piper, 2002). Bulk density by clod method as described by Black (1965). Available nitrogen in the soil was determined by modified alkaline permanganate method of Subbiah and Asija (1956) as described by Sahrawat and Burford (1982). Available phosphorous, potassium and sulphur by $\mathrm{NaHCO}_{3}$ extraction followed by spectrophotometry method, 1N Ammonium acetate extraction followed by flame photometric method and $0.1 \mathrm{~N} \mathrm{CaCl}_{2} \cdot 2 \mathrm{H}_{2} \mathrm{O}$ extraction followed by turbidimetry method respectively as described by Sparks (1996). Micronutrients (Fe and $\mathrm{Zn}$ ) by DTPA extraction fallowed by atomic absorption spectrophotometer method as described by Lindsay and Norvell (1978).

The experimental data obtained were subjected to statistical analysis as described by Gomez and Gomez (1984). The level of significance used in ' $\mathrm{F}$ ' test was $\mathrm{P}=0.05$. Critical differences were calculated wherever ' $F$ ' test was significant.

\section{Results and Discussion}

\section{Growth parameters of groundnut (cf Table} 2)

The significantly tallest plants were recorded in the treatment $\left(\mathrm{T}_{10}\right)$ which received soil application of $175 \% \mathrm{RD} \mathrm{N}, \mathrm{P}_{2} \mathrm{O}_{5}+75 \% \mathrm{~K}_{2} \mathrm{O}$ $(45.80 \mathrm{~cm})$ compared to control and rest of the treatments, except the treatment $\left(\mathrm{T}_{7}\right)$ with soil application of $150 \% \mathrm{RD} \mathrm{N}, \mathrm{P}_{2} \mathrm{O}_{5}+75 \% \mathrm{~K}_{2} \mathrm{O}$ $(45.00 \mathrm{~cm})$. Further, the treatment $\left(\mathrm{T}_{6}\right.$ and $\left.\mathrm{T}_{9}\right)$ with soil application of $150 \% \mathrm{RD} \mathrm{N}, \mathrm{P}_{2} \mathrm{O}_{5}+$ $50 \% \mathrm{~K}_{2} \mathrm{O}$ and $175 \% \mathrm{RD} \mathrm{N}, \mathrm{P}_{2} \mathrm{O}_{5}+50 \% \mathrm{~K}_{2} \mathrm{O}$ $(43.66$ and $43.26 \mathrm{~cm}$ ) were on par with each other but significantly superior over control and the treatment composed of $125 \%$ RD N and $\mathrm{P}_{2} \mathrm{O}$ along with ascending rate of potassium application i.e. 25, 50 and $75 \% \mathrm{RD}$ $\mathrm{K}_{2} \mathrm{O}\left(\mathrm{T}_{2}, \mathrm{~T}_{3}\right.$ and $\left.\mathrm{T}_{4}\right)$. The plant height of groundnut at 30 and 60 DAS ranged from 15.46 to $19.86 \mathrm{~cm}$ and 30.20 to $35.00 \mathrm{~cm}$ respectively and the effect of different treatments were similar with the observations made at harvest.

The significantly higher number of branches per plant i.e. 6.74 at harvest were recorded in the treatment $\left(\mathrm{T}_{10}\right)$ which received soil application of $175 \%$ RD N, $\mathrm{P}_{2} \mathrm{O}+75 \% \mathrm{~K}_{2} \mathrm{O}$ and was on par with the treatments $\left(\mathrm{T}_{7}\right.$ and $\left.\mathrm{T}_{9}\right)$ with the soil application $150 \% \mathrm{RD} \mathrm{N}, \mathrm{P}_{2} \mathrm{O}_{5}+$ $75 \% \mathrm{~K}_{2} \mathrm{O}$ and $175 \%$ RD N, $\mathrm{P}_{2} \mathrm{O}_{5}+50 \% \mathrm{~K}_{2} \mathrm{O}$ (6.70 and 6.26) but significantly superior over control and other treatments. Further, treatments $\left(\mathrm{T}_{4}\right.$ and $\left.\mathrm{T}_{3}\right)$ with soil application of $125 \% \mathrm{RD} \mathrm{N}, \mathrm{P}_{2} \mathrm{O}_{5}+75 \% \mathrm{~K}_{2} \mathrm{O}$ (6.06) and $125 \%$ RD N, $\mathrm{P}_{2} \mathrm{O}_{5}+50 \% \mathrm{~K}_{2} \mathrm{O}$ (5.94) were on par with each other but significantly superior over control.

Number branches per plant in groundnut at 30 DAS and 60 DAS ranged from 4.13 to 5.74 and 5.20 to 6.60 respectively. The effect of different treatments was similar to that observed at harvest and comparatively much 
changes were not observed from 60 DAS to the harvest time with respect number of branches.

The total dry matter ranges from 20.82 to $26.85 \mathrm{~g} \mathrm{plant}^{-1}$ at harvest. The facts of experimental outcomes convince that, the significantly higher total dry matter $(26.85 \mathrm{~g}$ plant $^{-1}$ ) was recorded in treatment $\left(\mathrm{T}_{10}\right)$ receiving $175 \% \mathrm{RD} \mathrm{N}, \mathrm{P}_{2} \mathrm{O}_{5}+75 \% \mathrm{~K}_{2} \mathrm{O}$ at harvest. Next to superior, the treatment $\left(\mathrm{T}_{7}\right)$ composed of $150 \%$ RD N, $\mathrm{P}_{2} \mathrm{O}_{5}+75 \% \mathrm{~K}_{2} \mathrm{O}$ was yielded 26.24 g plant $^{-1}$, stand insignificant with the treatment $T_{8}$ but significant with rest. The total dry matter of groundnut at 30 DAS and 60 DAS ranges from 4.76 to $6.78 \mathrm{~g} \mathrm{plant}^{-1}$ and 14.83 to $17.43 \mathrm{~g} \mathrm{plant}^{-1}$. The growth trend of groundnut among the different treatments at 30 DAS and 60 DAS has been recorded similar as at harvest. The increase in plant height, number of branches and total dry matter production at different growth stages might be due to the increased levels soil application of $P$. The development of extensive root system and nodulation, and thus enables plants to absorb more water and nutrients from varied depth of the soil with an indirect action of phosphorus element. This in turn could enhance the plant's ability to generate more assimilates which were reflected in the higher dry matter production. Similar results have been reported by ElHabbasha et al., 2005 and Gobarah et al., 2006.

Table.1 Initial physical and chemical properties of the soil of experimental site

\begin{tabular}{|c|c|c|c|}
\hline Sl. No. & Parameters & Units & Values \\
\hline A & \multicolumn{3}{|c|}{ Physical properties } \\
\hline \multirow[t]{4}{*}{1} & \multicolumn{3}{|c|}{ Particle size distribution (per cent oven dry basis) } \\
\hline & Sand & \multirow[t]{3}{*}{$\%$} & 21.65 \\
\hline & Silt & & 19.35 \\
\hline & Clay & & 59.00 \\
\hline 2 & Texture & & Clay \\
\hline 3 & Bulk density & \multirow[t]{2}{*}{$\mathrm{Mg} \mathrm{m}^{-3}$} & 1.28 \\
\hline 4 & Particle density & & 2.62 \\
\hline 5 & Pore space & $\%$ & 51.14 \\
\hline B & \multicolumn{3}{|c|}{ Chemical properties } \\
\hline 1 & Soil reaction $(1: 2.5)$ & & 8.4 (Moderately alkaline) \\
\hline 2 & Electrical conductivity $(1: 2.5)$ & $\mathrm{dS} \mathrm{m}^{-1}$ & $0.22($ Normal $)$ \\
\hline 3 & Free $\mathrm{CaCO}_{3}$ content & $\%$ & 11.5 (Moderately calcareous) \\
\hline 4 & Soil organic carbon & $\mathrm{g} \mathrm{kg}^{-1}$ & $3.75($ Low $)$ \\
\hline C & \multicolumn{3}{|c|}{ Fertility status } \\
\hline 1 & Available Nitrogen & \multirow[t]{4}{*}{$\mathrm{kg} \mathrm{ha}^{-1}$} & 180 (Low) \\
\hline 2 & Available Phosphorous & & 20.5 (Low) \\
\hline 3 & Available Potassium & & 351 (High) \\
\hline 4 & Available Sulphur & & 17.5 (Medium) \\
\hline 5 & Available Zinc & \multirow[t]{2}{*}{$\mathrm{mg} \mathrm{kg}^{-1}$} & 0.42 (Deficit) \\
\hline 6 & Available Iron & & 4.8 (Sufficient) \\
\hline
\end{tabular}


Table.2 Effect of soil application of major nutrients on growth parameters of groundnut

\begin{tabular}{|c|c|c|c|c|c|c|c|c|c|}
\hline \multirow[t]{2}{*}{ Treatment details } & \multicolumn{3}{|c|}{ Plant height $(\mathrm{cm})$} & \multicolumn{3}{|c|}{ No. of branches plant ${ }^{-1}$} & \multicolumn{3}{|c|}{ Total dry matter (g plant $\left.{ }^{-1}\right)$} \\
\hline & 30 DAS & 60 DAS & At harvest & 30 DAS & 60 DAS & At harvest & 30 DAS & 60 DAS & At harvest \\
\hline $\mathbf{T}_{1}: \mathbf{R P P}($ control) & 15.46 & 30.20 & 40.13 & 4.13 & 5.20 & 5.20 & 4.76 & 14.83 & 20.82 \\
\hline $\mathrm{T}_{2}: 125 \% \mathrm{RD} \mathrm{N}, \mathrm{P}_{2} \mathrm{O}_{5}+25 \% \mathrm{~K}_{2} \mathrm{O}$ & 17.20 & 31.60 & 41.80 & 4.74 & 5.60 & 5.60 & 5.02 & 15.09 & 22.13 \\
\hline $\mathrm{T}_{3}: 125 \% \mathrm{RD} \mathrm{N}, \mathrm{P}_{2} \mathrm{O}_{5}+50 \% \mathrm{~K}_{2} \mathrm{O}$ & 17.66 & 31.73 & 42.33 & 5.20 & 5.80 & 5.94 & 5.36 & 15.47 & 22.72 \\
\hline $\mathrm{T}_{4}: 125 \% \mathrm{RD} \mathrm{N}, \mathrm{P}_{2} \mathrm{O}_{5}+75 \% \mathrm{~K}_{2} \mathrm{O}$ & 18.06 & 32.33 & 43.33 & 5.00 & 6.00 & 6.06 & 5.67 & 16.40 & 24.04 \\
\hline $\mathrm{T}_{5}: 150 \% \mathrm{RD} \mathrm{N}, \mathrm{P}_{2} \mathrm{O}_{5}+25 \% \mathrm{~K}_{2} \mathrm{O}$ & 18.46 & 33.86 & 42.26 & 5.40 & 6.00 & 6.12 & 5.78 & 16.55 & 24.53 \\
\hline $\mathrm{T}_{6}: 150 \% \mathrm{RD} \mathrm{N}, \mathrm{P}_{2} \mathrm{O}_{5}+\mathbf{5 0} \% \mathrm{~K}_{2} \mathrm{O}$ & 19.26 & 34.20 & 43.66 & 5.46 & 6.20 & 6.20 & 6.15 & 16.94 & 25.16 \\
\hline $\mathrm{T}_{7}: 150 \% \mathrm{RD} \mathrm{N}, \mathrm{P}_{2} \mathrm{O}_{5}+75 \% \mathrm{~K}_{2} \mathrm{O}$ & 19.80 & 34.66 & 45.00 & 5.66 & 6.54 & 6.70 & 6.60 & 17.28 & 26.24 \\
\hline $\mathrm{T}_{8}: 175 \% \mathrm{RD} \mathrm{N}, \mathrm{P}_{2} \mathrm{O}_{5}+25 \% \mathrm{~K}_{2} \mathrm{O}$ & 18.94 & 33.86 & 42.93 & 5.20 & 6.00 & 6.00 & 6.06 & 16.60 & 25.48 \\
\hline $\mathrm{T}_{9}: 175 \% \mathrm{RD} \mathrm{N}, \mathrm{P}_{2} \mathrm{O}_{5}+50 \% \mathrm{~K}_{2} \mathrm{O}$ & 19.34 & 34.26 & 43.26 & 5.54 & 6.20 & 6.26 & 6.18 & 16.94 & 25.94 \\
\hline $\mathrm{T}_{10}: 175 \% \mathrm{RD} \mathrm{N}, \mathrm{P}_{2} \mathrm{O}_{5}+75 \% \mathrm{~K}_{2} \mathrm{O}$ & 19.86 & 35.00 & 45.80 & 5.74 & 6.60 & 6.74 & 6.78 & 17.43 & 26.85 \\
\hline S.Em \pm & 0.15 & 0.21 & 0.36 & 0.16 & 0.11 & 0.10 & 0.07 & 0.10 & 0.15 \\
\hline CD (0.05) & 0.49 & 0.69 & 1.18 & 0.52 & 0.35 & 0.34 & 0.23 & 0.33 & 0.49 \\
\hline CV (\%) & 7.45 & 6.12 & 8.48 & 5.42 & 4.21 & 4.04 & 8.77 & 10.11 & 10.95 \\
\hline
\end{tabular}

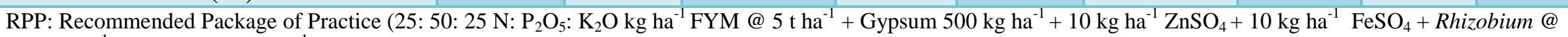
$1000 \mathrm{~g} \mathrm{ha}^{-1}+$ PSB @ $1000 \mathrm{~g} \mathrm{ha}^{-1}$ )

Foliar spray of boron $1.25 \mathrm{~g} \mathrm{~L}^{-1}$ was applied 30 DAS for all the treatments

RPP is common for all the treatments

DAS - Days after sowing 
Table.3 Effect of soil application of major nutrients on yield parameters of groundnut

\begin{tabular}{|c|c|c|c|c|}
\hline \multirow[t]{2}{*}{ Treatment details } & \multirow[t]{2}{*}{ No. of pods plant ${ }^{-1}$} & Pod wt. plant ${ }^{-1}$ & Shelling per cent & Test weight \\
\hline & & (g) & $(\%)$ & (g) \\
\hline $\mathrm{T}_{1}: \mathbf{R P P}$ (control) & 18.40 & 08.32 & 71.75 & 35.30 \\
\hline $\mathrm{T}_{2}: 125 \% \mathrm{RD} \mathrm{N}, \mathrm{P}_{2} \mathrm{O}_{5}+25 \% \mathrm{~K}_{2} \mathrm{O}$ & 19.86 & 09.29 & 72.56 & 36.70 \\
\hline $\mathrm{T}_{3}: 125 \% \mathrm{RD} \mathrm{N}, \mathrm{P}_{2} \mathrm{O}_{5}+50 \% \mathrm{~K}_{2} \mathrm{O}$ & 20.60 & 09.54 & 72.90 & 36.42 \\
\hline $\mathrm{T}_{4}: 125 \% \mathrm{RD} \mathrm{N}, \mathrm{P}_{2} \mathrm{O}_{5}+75 \% \mathrm{~K}_{2} \mathrm{O}$ & 21.26 & 10.21 & 73.25 & 37.90 \\
\hline $\mathrm{T}_{5}: 150 \% \mathrm{RD} \mathrm{N}, \mathrm{P}_{2} \mathrm{O}_{5}+25 \% \mathrm{~K}_{2} \mathrm{O}$ & 21.60 & 10.66 & 73.52 & 39.15 \\
\hline $\mathrm{T}_{6}: 150 \% \mathrm{RD} \mathrm{N}, \mathrm{P}_{2} \mathrm{O}_{5}+50 \% \mathrm{~K}_{2} \mathrm{O}$ & 21.86 & 10.96 & 74.21 & 39.80 \\
\hline $\mathrm{T}_{7}: 150 \% \mathrm{RD} \mathrm{N}, \mathrm{P}_{2} \mathrm{O}_{5}+75 \% \mathrm{~K}_{2} \mathrm{O}$ & 21.73 & 11.28 & 75.18 & 41.50 \\
\hline $\mathrm{T}_{8}: 175 \% \mathrm{RD} \mathrm{N}, \mathrm{P}_{2} \mathrm{O}_{5}+25 \% \mathrm{~K}_{2} \mathrm{O}$ & 22.13 & 10.72 & 72.87 & 38.10 \\
\hline $\mathrm{T}_{9}: 175 \% \mathrm{RD} \mathrm{N}, \mathrm{P}_{2} \mathrm{O}_{5}+50 \% \mathrm{~K}_{2} \mathrm{O}$ & 22.26 & 10.94 & 74.64 & 39.26 \\
\hline $\mathrm{T}_{10}: 175 \% \mathrm{RD} \mathrm{N}, \mathrm{P}_{2} \mathrm{O}_{5}+75 \% \mathrm{~K}_{2} \mathrm{O}$ & 22.46 & 11.62 & 75.34 & 41.66 \\
\hline S.Em \pm & 0.23 & 0.06 & 0.23 & 0.27 \\
\hline CD (0.05) & 0.74 & 0.20 & 0.73 & 0.87 \\
\hline CV (\%) & 7.01 & 6.62 & 4.32 & 5.22 \\
\hline
\end{tabular}

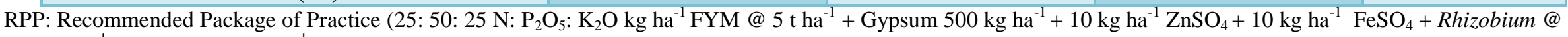
$1000 \mathrm{~g} \mathrm{ha}^{-1}+$ PSB @ $1000 \mathrm{~g} \mathrm{ha}^{-1}$ )

Foliar spray of boron $1.25 \mathrm{~g} \mathrm{~L}^{-1}$ was applied $30 \mathrm{DAS}$ for all the treatments

$\mathrm{RPP}$ is common for all the treatments

TDM - Total dry matter

Test weight : 100 kernel weight 
Int.J.Curr.Microbiol.App.Sci (2019) 8(12): $\mathrm{xx}-\mathrm{xx}$

Table.4 Effect of soil application of major nutrients on yield of groundnut

\begin{tabular}{|c|c|c|c|c|}
\hline \multirow[t]{2}{*}{ Treatment details } & Pod yield & Kernel yield & Haulm yield & TDM \\
\hline & \multicolumn{4}{|c|}{$\left(\mathrm{kg} \mathrm{ha}^{-1}\right)$} \\
\hline $\mathbf{T}_{1}: \mathbf{R P P}($ control) & 2104 & 1510 & 3156 & 5260 \\
\hline $\mathrm{T}_{2}: 125 \% \mathrm{RD} \mathrm{N}, \mathrm{P}_{2} \mathrm{O}_{5}+25 \% \mathrm{~K}_{2} \mathrm{O}$ & 2349 & 1704 & 3244 & 5593 \\
\hline $\mathrm{T}_{3}: \mathbf{1 2 5} \% \mathrm{RD} \mathrm{N}, \mathrm{P}_{2} \mathrm{O}_{5}+50 \% \mathrm{~K}_{2} \mathrm{O}$ & 2412 & 1758 & 3330 & 5742 \\
\hline $\mathrm{T}_{4}: 125 \% \mathrm{RD} \mathrm{N}, \mathrm{P}_{2} \mathrm{O}_{5}+75 \% \mathrm{~K}_{2} \mathrm{O}$ & 2582 & 1891 & 3493 & 6075 \\
\hline $\mathrm{T}_{5}: 150 \% \mathrm{RD} \mathrm{N}, \mathrm{P}_{2} \mathrm{O}_{5}+25 \% \mathrm{~K}_{2} \mathrm{O}$ & 2696 & 1982 & 3522 & 6218 \\
\hline $\mathrm{T}_{6}: \mathbf{1 5 0} \% \mathrm{RD} \mathrm{N}, \mathrm{P}_{2} \mathrm{O}_{5}+50 \% \mathrm{~K}_{2} \mathrm{O}$ & 2772 & 2057 & 3586 & 6358 \\
\hline $\mathrm{T}_{7}: 150 \% \mathrm{RD} \mathrm{N}, \mathrm{P}_{2} \mathrm{O}_{5}+75 \% \mathrm{~K}_{2} \mathrm{O}$ & 2851 & 2148 & 3780 & 6631 \\
\hline $\mathrm{T}_{8}: 175 \% \mathrm{RD} \mathrm{N}, \mathrm{P}_{2} \mathrm{O}_{5}+25 \% \mathrm{~K}_{2} \mathrm{O}$ & 2711 & 1975 & 3713 & 6424 \\
\hline $\mathrm{T}_{9}: 175 \% \mathrm{RD} \mathrm{N}, \mathrm{P}_{2} \mathrm{O}_{5}+50 \% \mathrm{~K}_{2} \mathrm{O}$ & 2766 & 2064 & 3790 & 6556 \\
\hline $\mathrm{T}_{10}: 175 \% \mathrm{RD} \mathrm{N}, \mathrm{P}_{2} \mathrm{O}_{5}+75 \% \mathrm{~K}_{2} \mathrm{O}$ & 2898 & 2209 & 3848 & 6746 \\
\hline S.Em \pm & 16.29 & 14.14 & 22.23 & 38.52 \\
\hline CD (0.05) & 52.11 & 45.24 & 71.12 & 123.22 \\
\hline CV (\%) & 7.94 & 7.26 & 10.86 & 10.80 \\
\hline
\end{tabular}

RPP: Recommended Package of Practice (25: 50: $25 \mathrm{~N}: \mathrm{P}_{2} \mathrm{O}_{5}: \mathrm{K}_{2} \mathrm{O} \mathrm{kg} \mathrm{ha}{ }^{-1} \mathrm{FYM} @ 5 \mathrm{t} \mathrm{ha}^{-1}+\mathrm{Gypsum}_{500 \mathrm{~kg} \mathrm{ha}}^{-1}+10 \mathrm{~kg} \mathrm{ha}^{-1} \mathrm{ZnSO}_{4}+10 \mathrm{~kg} \mathrm{ha}^{-1} \mathrm{FeSO}_{4}+$ Rhizobium @ $1000 \mathrm{~g} \mathrm{ha}^{-1}$ + PSB @ $1000 \mathrm{~g} \mathrm{ha}^{-1}$ )

Foliar spray of boron $1.25 \mathrm{~g} \mathrm{~L}^{-1}$ was applied 30 DAS for all the treatments

RPP is common for all the treatments TDM - Total dry matter 
Table.5 Effect of soil application of major nutrients on quality parameters of groundnut

\begin{tabular}{|c|c|c|c|c|}
\hline Treatment details & Oil content $(\%)$ & Oil yield (kg ha $\left.{ }^{-1}\right)$ & $\mathrm{N}$ conc. in kernel $(\%)$ & *Crude protein content $(\%)$ \\
\hline $\mathbf{T}_{1}: \mathbf{R P P}($ control $)$ & 43.48 & 656 & 3.08 & 19.25 \\
\hline $\mathrm{T}_{3}: 125 \% \mathrm{RD} \mathrm{N}, \mathrm{P}_{2} \mathrm{O}_{5}+50 \% \mathrm{~K}_{2} \mathrm{O}$ & 43.49 & 764 & 3.12 & 19.52 \\
\hline $\mathrm{T}_{5}: 150 \% \mathrm{RD} \mathrm{N}, \mathrm{P}_{2} \mathrm{O}_{5}+25 \% \mathrm{~K}_{2} \mathrm{O}$ & 44.07 & 873 & 3.20 & 20.02 \\
\hline $\mathrm{T}_{6}: 150 \% \mathrm{RD} \mathrm{N}, \mathrm{P}_{2} \mathrm{O}_{5}+50 \% \mathrm{~K}_{2} \mathrm{O}$ & 44.51 & 915 & 3.24 & 20.27 \\
\hline $\mathrm{T}_{7}: 150 \% \mathrm{RD} \mathrm{N}, \mathrm{P}_{2} \mathrm{O}_{5}+75 \% \mathrm{~K}_{2} \mathrm{O}$ & 44.63 & 958 & 3.32 & 20.79 \\
\hline$T_{10}: 175 \%$ RD N, $P_{2} O_{5}+75 \% K_{2} O$ & 44.67 & 986 & 3.55 & 22.20 \\
\hline S.Em \pm & 0.11 & 6.27 & 0.02 & 0.16 \\
\hline CD (0.05) & 0.35 & 20.08 & 0.08 & 0.51 \\
\hline CV $(\%)$ & 2.65 & 1.27 & 1.37 & 1.37 \\
\hline
\end{tabular}

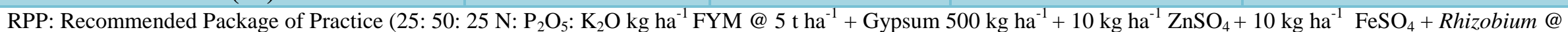
$1000 \mathrm{~g} \mathrm{ha}^{-1}+$ PSB @ $\left.1000 \mathrm{~g} \mathrm{ha}^{-1}\right)$

Foliar spray of boron $1.25 \mathrm{~g} \mathrm{~L}^{-1}$ was applied $30 \mathrm{DAS}$ for all the treatments

RPP is common for all the treatments

* Crude protein content: $\mathrm{N}$ conc. in kernel $(\%) \times 6.25$ 


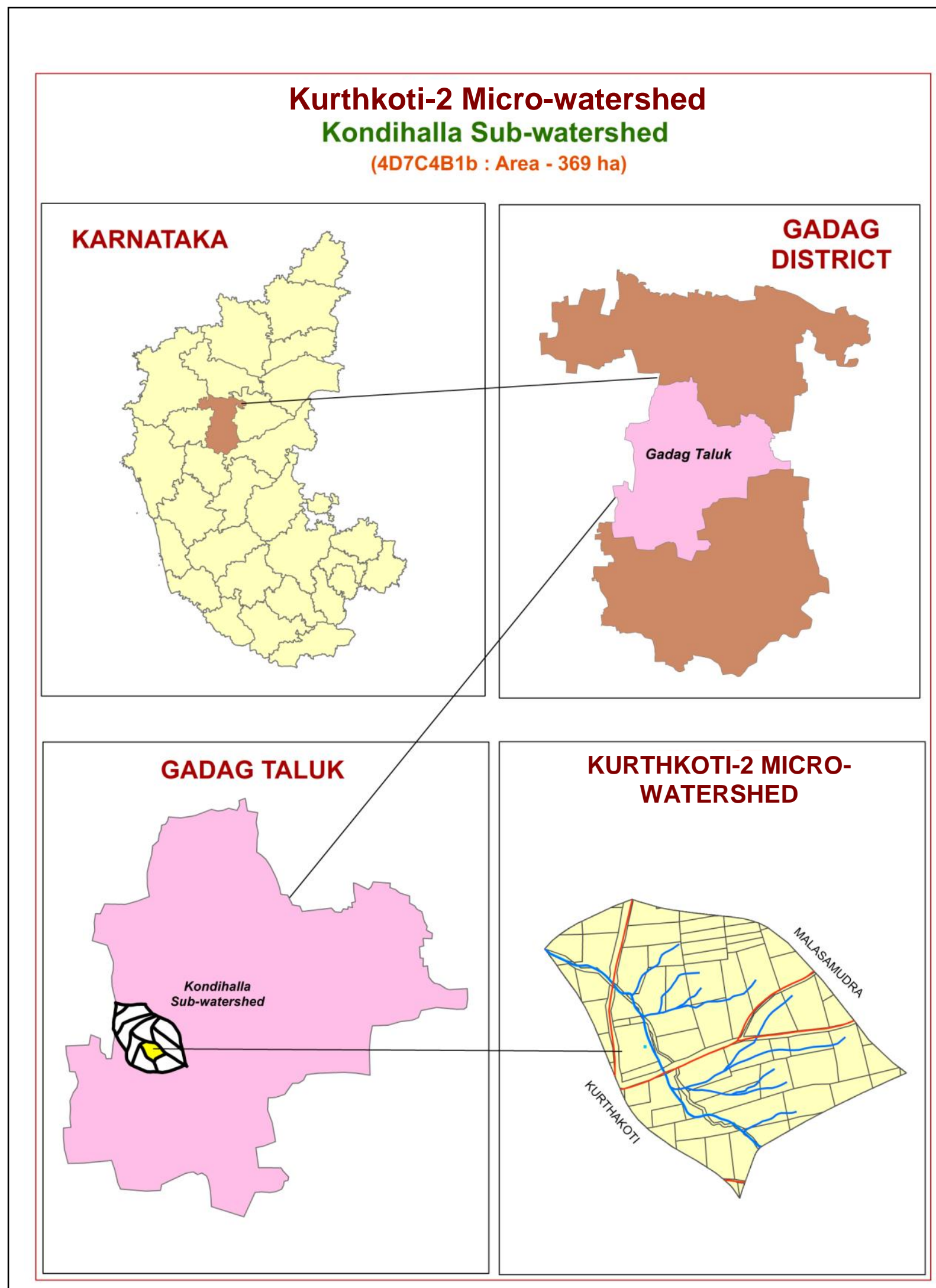

Fig.1 Location of the experimental site 


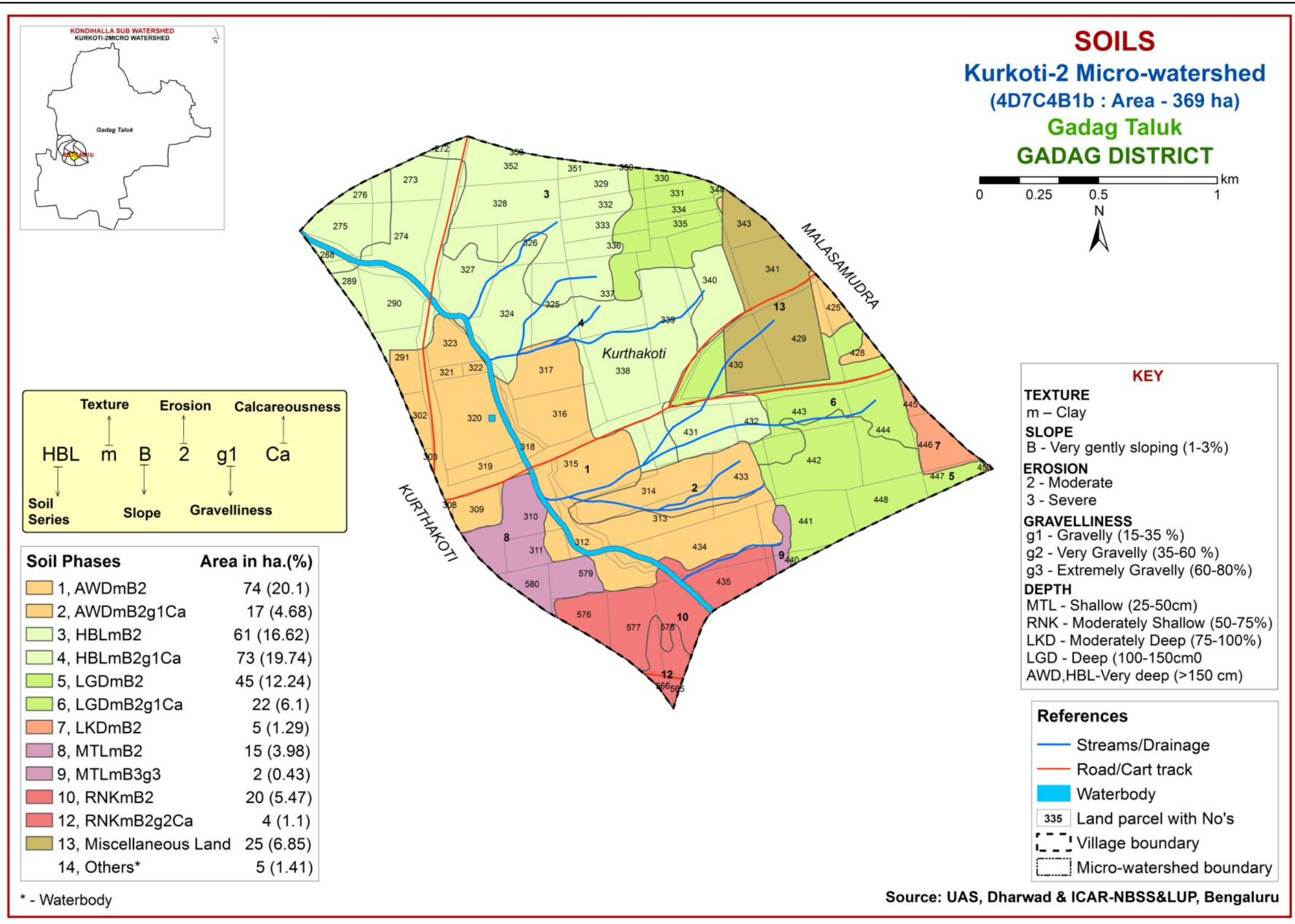

Fig.2 Soil characteristics at experimentation site 


\section{Yield attributes (cf Table 3)}

The number of pods per plant ranged from 18.40 to 22.46 and significantly influenced due to the soil application of major nutrients at varied levels. The significantly more number of pods per plant were recorded in the treatment $\left(\mathrm{T}_{10}\right)$ which received soil application of $175 \% \mathrm{RD} \mathrm{N}, \mathrm{P}_{2} \mathrm{O}_{5}+75 \% \mathrm{~K}_{2} \mathrm{O}$ (22.46) compared to control and rest of the treatments except the treatments $\left(\mathrm{T}_{9}, \mathrm{~T}_{8}\right.$ and $\left.\mathrm{T}_{7}\right)$ with soil application of $175 \%$ RD N, $\mathrm{P}_{2} \mathrm{O}_{5}+50 \% \mathrm{~K}_{2} \mathrm{O}$, $175 \%$ RD N, $\mathrm{P}_{2} \mathrm{O}_{5}+25 \% \mathrm{~K}_{2} \mathrm{O}$ and $150 \%$ RD N, $\mathrm{P}_{2} \mathrm{O}_{5}+75 \% \mathrm{~K}_{2} \mathrm{O}(22.26,22.13$ and 21.85) nutrients. Further, the pod weight ranged from 8.32 to $11.62 \mathrm{~g} \mathrm{plant}^{-1}$ and the significantly higher pod weight plant ${ }^{-1}(11.62$ $\mathrm{g}$ plant $\left.^{-1}\right)$ was recorded in treatment $\left(\mathrm{T}_{10}\right)$ receiving $175 \% \mathrm{RD} \mathrm{N}, \mathrm{P}_{2} \mathrm{O}_{5}+75 \% \mathrm{~K}_{2} \mathrm{O}$ at harvest. Next to superior, the treatment $\left(\mathrm{T}_{7}\right)$ composed of $150 \%$ RD N, $\mathrm{P}_{2} \mathrm{O}_{5}+75 \% \mathrm{~K}_{2} \mathrm{O}$ was yielded $11.28 \mathrm{~g}$ plant $^{-1}$, stands insignificant with the treatment $T_{10}$ but significant with rest of treatments. The significantly maximum shelling per cent was recorded in the treatment $\left(\mathrm{T}_{10}\right)$ which received soil application of $175 \% \mathrm{RD} \mathrm{N}, \mathrm{P}_{2} \mathrm{O}_{5}+75 \%$ $\mathrm{K}_{2} \mathrm{O}(75.34 \%)$ compared to control and rest of the treatments except the treatments $\left(\mathrm{T}_{7}\right.$ and $\mathrm{T}_{9}$ ) with soil application of $150 \% \mathrm{RD} \mathrm{N}, \mathrm{P}_{2} \mathrm{O}_{5}$ $+75 \% \mathrm{~K}_{2} \mathrm{O}$ and $175 \% \mathrm{RD} \mathrm{N}, \mathrm{P}_{2} \mathrm{O}_{5}+50 \%$ $\mathrm{K}_{2} \mathrm{O}$ (75.18 and $\left.74.64 \%\right)$.

The test weight of 100 kernels was ranged from 35.30 to $41.66 \mathrm{~g}$. The data revealed that the maximum test weight i.e. $41.66 \mathrm{~g}$ was recorded in the treatment $\left(\mathrm{T}_{10}\right)$ which received soil application of $175 \% \mathrm{RD} \mathrm{N}, \mathrm{P}_{2} \mathrm{O}_{5}+75 \%$ $\mathrm{K}_{2} \mathrm{O}$ and was on par with the treatment $\left(\mathrm{T}_{7}\right)$ with the soil application $150 \% \mathrm{RD} \mathrm{N}, \mathrm{P}_{2} \mathrm{O}_{5}+$ $75 \% \mathrm{~K}_{2} \mathrm{O}(41.50 \mathrm{~g})$ but significantly superior over control and other treatments. The increase in yield due to increased dose of $\mathrm{P}$ fertilizer may be attributed to the activation of metabolic processes, where its role in building phospholipids and nucleic acid is known. The pronounced dose of $\mathrm{N}$ resulted in development and maintenance of chlorophyll and photosynthetic area in terms of leaf area index which in turn attributed to higher photosynthetic rate. In addition, an element $\mathrm{K}$ responsible for mobility would account for maximum translocation of photosynthates from leaves to the developing pods i.e. source to sink movement. Certainly this combination leads to more pods to gynophores ratio and ultimately higher pod yield.

Hence, the additional 50 per cent nitrogen in combination with 25 per cent deficit potassium recorded significantly higher pod yield compared to control that received only RDF. The results were proximal to the findings of Balasubramanian and Palaniappan (1996).

\section{Yield (cf Table 4)}

The pod yield ranged from 2104 to $2898 \mathrm{~kg}$ $\mathrm{ha}^{-1}$. The maximum pod yield i.e. $2898 \mathrm{~kg} \mathrm{ha}^{-1}$ was recorded in the treatment $\left(\mathrm{T}_{10}\right)$ which received soil application of $175 \% \mathrm{RD} \mathrm{N}, \mathrm{P}_{2} \mathrm{O}_{5}$ $+75 \% \mathrm{~K}_{2} \mathrm{O}$ and was on par with the treatment $\left(\mathrm{T}_{7}\right)$ with the soil application $150 \% \mathrm{RD} \mathrm{N}$, $\mathrm{P}_{2} \mathrm{O}_{5}+75 \% \mathrm{~K}_{2} \mathrm{O}\left(2851 \mathrm{~kg} \mathrm{ha}^{-1}\right)$ but significantly superior over control and other treatments. Further, treatments $\left(\mathrm{T}_{9}\right.$ and $\left.\mathrm{T}_{8}\right)$ with soil application of $175 \% \mathrm{RD} \mathrm{N}, \mathrm{P}_{2} \mathrm{O}_{5}+$ $50 \% \mathrm{~K}_{2} \mathrm{O}\left(2766 \mathrm{~kg} \mathrm{ha}^{-1}\right)$ and $175 \% \mathrm{RD} \mathrm{N}$, $\mathrm{P}_{2} \mathrm{O}_{5}+25 \% \mathrm{~K}_{2} \mathrm{O}\left(2711 \mathrm{~kg} \mathrm{ha}^{-1}\right)$ were statistically on par with each other but significantly superior over the control. The rest treatments were statistically significant with each other and over the control. Similarly, the kernel yield as product of pod yield and shelling per cent do followed congruent trend with respect to yield. The haulm yield ranged from 3156 to $3848 \mathrm{~kg} \mathrm{ha}^{-1}$. The significantly maximum haulm yield ( 3848 $\mathrm{kg} \mathrm{ha}{ }^{-1}$ ) was recorded in the treatment composed of $175 \%$ RD N, $\mathrm{P}_{2} \mathrm{O}+75 \% \mathrm{~K}_{2} \mathrm{O}$ nutrients and was on par with the treatments ( $\mathrm{T}_{9}$ and $\mathrm{T}_{7}$ ) with the soil application $175 \% \mathrm{RD}$ 
$\mathrm{N}, \mathrm{P}_{2} \mathrm{O}_{5}+50 \% \mathrm{~K}_{2} \mathrm{O}$ and $150 \% \mathrm{RD} \mathrm{N}, \mathrm{P}_{2} \mathrm{O}_{5}+$ $\left.\begin{array}{lllllll}75 & \% & \mathrm{~K}_{2} \mathrm{O} & (3790 & \text { and } 3780 \mathrm{~kg} \mathrm{ha}^{-1}\end{array}\right)$ but significantly superior over control and other treatments.

Yield being a complex character, is the sum of many morphological and biological events that occur during the crop growth and development (Thorave and Dhonde, 2007). The improvement in yield attributing parameters in groundnut might be correlated to the better establishment, improvement in the availability of plant nutrients and efficient translocation of photosynthates. This work is in conformity with Muralidharan et al., (2002) in sugarcane and Nandakumar et al., (2004) in rice.

\section{Quality attributes (cf Table 5)}

The oil content in groundnut kernels ranged from 43.25 to 44.67 per cent and the significantly maximum oil content i.e. 44.67 per cent was recorded in the treatment $\left(\mathrm{T}_{10}\right)$ which received soil application of $175 \% \mathrm{RD}$ $\mathrm{N}, \mathrm{P}_{2} \mathrm{O}+75 \% \mathrm{~K}_{2} \mathrm{O}$ and was on par with the treatment $\left(\mathrm{T}_{7}, \mathrm{~T}_{9}\right.$ and $\left.\mathrm{T}_{6}\right)$ with the soil application $150 \%$ RD N, $\mathrm{P}_{2} \mathrm{O}_{5}+75 \% \mathrm{~K}_{2} \mathrm{O}$, $175 \% \mathrm{RD} \mathrm{N}, \mathrm{P}_{2} \mathrm{O}_{5}+50 \% \mathrm{~K}_{2} \mathrm{O}$ and $150 \%$ $\mathrm{RD} \mathrm{N}, \mathrm{P}_{2} \mathrm{O}_{5}+50 \% \mathrm{~K}_{2} \mathrm{O}$ (44.63, 44.59 and $44.51 \%$ ) but significantly superior over control and other treatments.

The treatments composed of $125 \% \mathrm{RD} \mathrm{N}$ and $\mathrm{P}_{2} \mathrm{O}_{5}$ were statistically insignificant irrespective of $\mathrm{K}_{2} \mathrm{O}$ doses but significant over the control. Further, the oil yield ranged from 656 to $986 \mathrm{~kg} \mathrm{ha}^{-1}$ which was product of oil content, shelling per cent and pod yield. There will more pronounced effect of $\mathrm{P}$ on $\mathrm{S}$ uptake compared with effect $\mathrm{S}$ on $\mathrm{P}$ uptake due to the fact that $\mathrm{PO}_{4}{ }^{2-}$ ions being a strong competitor for adsorption sites, causing desorption of $\mathrm{SO}_{4}{ }^{2-}$ and consequently increasing $\mathrm{S}$ mobility. Similar results are recorded in Chandra and Khaldelwal (2009) who reported increased uptake of $\mathrm{P}$ and $\mathrm{S}$ in chickpea.
The significantly maximum crude protein content was recorded in the treatment which received $175 \% \mathrm{RD} \mathrm{N}, \mathrm{P}_{2} \mathrm{O}+75 \% \mathrm{~K}_{2} \mathrm{O}$ $(22.20 \%)$ and least was recorded in control that received purely RPP (19.25\%). Further the treatment $\left(\mathrm{T}_{9}\right) 175 \% \mathrm{RD} \mathrm{N}, \mathrm{P}_{2} \mathrm{O}_{5}+50 \%$ $\mathrm{K}_{2} \mathrm{O}(21.77 \%)$ was on par with $\mathrm{T}_{10}$ and significant over the control. Crude protein content being dependent factor on $\mathrm{N}$ concentration in kernel made significant difference among the graded doses of soil application nitrogenous fertilizers.

Soil application of $175 \%$ RD N, $\mathrm{P}_{2} \mathrm{O}+75 \%$ $\mathrm{K}_{2} \mathrm{O}$ nutrients resulted in significantly higher pod yield of $2898 \mathrm{~kg} \mathrm{ha}^{-1}$ with an increase in the oil $(44.67 \%)$ and protein $(22.20 \%)$ contents in kernel. However, the treatment composed of $150 \% \mathrm{RD} \mathrm{N}, \mathrm{P}_{2} \mathrm{O}+75 \% \mathrm{~K}_{2} \mathrm{O}$ was found be on par with many yield parameters can be recommended in similar fertility constraints areas.

\section{Acknowledgement}

The study was carried out with the help of Sujala-III project funded by World Bank through Government of Karnataka. The authors duly acknowledge the support.

\section{References}

Balasubramanian, P. and Palaniappan, S. P., 1996, Time of NK application and its effect on irrigated groundnut. Madras Agric. J., 83(12): 750-753.

Black, C. A., 1968, Soil plant relationship. 2nd Ed. John Wiley and Sons, Inc. New York, London, pp. 403-414.

Chandra, D. and Khaldewal, R. B., 2009, Effect of $\mathrm{P}$ and $\mathrm{S}$ nutrition on yield and quality of chickpea. J. Indian Soc. Sci., 57(3): 352-356.

Das, D., Dwivedi, B. S., Meena, M. C., Singh, V. K. and Tiwari, K. N., 2015, Integrated nutrient management for improving soil health and crop 
productivity. Indian J. Fert., 11: 64-83.

El-Habbasha, S. F., Kandil, A. A., Khalfallah, M. A. and Behairy, T., 2005, Effect of phosphorus levels and some biofertilizers on dry matter, yield and yield attributes of groundnut. Int. J. Agron., 56: 237-252.

Gobarah, M. E., Mohammad, M. H. and Tawfik, M. M., 2006, Effect of phosphorus fertilizer and foliar spraying with zinc on growth, yield and quality of groundnut under reclaimed sandy soils. J. Appl. Sci. Res. Pakistan, 2: 491-496.

Gomez, K. A. and Gomez, A. A., 1984, Statistical Procedure for Agricultural Research. $2^{\text {nd }}$ Ed. John Wiley and Sons. New York, pp. 639.

Lindsay, W. L. and Norvell, W. A., 1978, Development of DTPA test zinc, iron, manganese and copper. J. Soil Sci. Soc. America, 42: 421-428.

Muralidharan, R. G., Selvakumari, G. and Singaram, P., 2002, Effect of humic acid on soil fertility, yield and quality of sugarcane. In: Proc. $67^{\text {th }}$ Annual convention: National Seminar on developments in Soil Science, Tamil Nadu (India), pp. 22-25.

Nandakumar, R., Saravanan, A., Singaram, P. and Chandrasekaran, B. S., 2004,
Effect of lignite humic acid on soil nutrient availability at different growth stages of rice grown on Vertisols and Alfisols. Acta. Agron. Hungarica, 52(3): 227-235.

Piper, C. S., 2002, Soil and Plant Analysis, Hans Publications, Bombay, India. pp. 56-64.

Sahrawat, K. L. and Burford, J. R., 1982, Modification in the alkaline permanganate method for assessing the availability of soil nitrogen in upland soils. Soil Sci., 133(1-6): 53-57.

Sparks, D. L., 1996, Methods of Soil Analysis Part-3: Chemical Methods. Soil Sci. Soc. America, U.S.A. pp. 551-961.

Srinivasarao, C., 2011, Nutrient management strategies in rainfed agriculture: constraints and opportunities. Indian J. Fert., 7(4):12-28.

Subbiah, B. V. and Asija, G. L., 1956, A rapid procedure for the estimation of available nitrogen in soils. Current Sci., 25: 259-260.

Thorave, D. S. and Dhonde, M. B., 2007, Morphological indices and yield attributes as influenced by integrated nutrient management in summer groundnut. Ann. Plant Physio., 21(2): 186-188.

\section{How to cite this article:}

Malatesh Kambali and Gundlur, S. S. 2020. Effect of Soil Fertility Constraints based Nutrient Management on Growth, Yield and Quality Parameters of Groundnut (Arachis hypogaea L.) at Kurthkoti-2 Micro-watershed, Gadag. Int.J.Curr.Microbiol.App.Sci. 9(6): 4024-4036. doi: https://doi.org/10.20546/ijcmas.2020.906.471 